\title{
EFFECTS OF SHOOT HEADING ON THREE CANOPY VASE FORMS OF APRICOT TREES (Armeniaca vulgaris Lam.)
}

\author{
Michał Szklarz, Bożena Radajewska, Monika Kluczyńska \\ and Ewa Głowacka \\ Poznań University of Life Sciences \\ Dąbrowskiego 159, 60-594 Poznań, POLAND \\ e-mail: mszklarz@up.poznan.pl
}

(Received July 2, 2012/Accepted October 16, 2012)

\begin{abstract}
A B S T R A C T
The study was carried out in the Przybroda experimental orchard near Poznań, Poland, using the three apricot cultivars: Goldrich, Hargrand and Sirena. The trees were trained to three canopy vase forms. Every year, in spring, shortly after the blooming period, apricot tree shoots were shortened by one half, or by one third of their length. The control trees were not shortened. The influence of the shortening of the shoots on tree growth, morphology of fruit bearing zone, flower bud setting, and tree yielding was studied. Trees with shoots shortened by one half of their length developed a greater number of branched shoots than the control trees, but, at the same time, they developed less spurs. The best yielding results were obtained from the 'Sirena' trees, while the lowest yielding results were obtained from 'Goldrich'. Trees with a vase canopy form, with 7-9 limbs and branches, and with shoots shortened by one third of their length, yielded better than the trees of the two other canopy forms.
\end{abstract}

Key words: apricot trees (Armeniaca vulgaris Lam.), fruiting, growth pattern, pruning, training

\section{INTRODUCTION}

During early development, apricot trees in good habitats are characterized by a strong monopodial and elongation growth caused by apical domination (Philips, 1975), creating very loose, wide tree canopies. In our experiment, we also observed such characteristic features during the first few years that the young trees were growing (Szklarz et al., 2011). Researchers are convinced that auxins produced by the shoot top are the main factor which impedes the development of axillary buds (McIntyre, 1964). 
The most popular apricot tree canopy form is the vase form. But there is not enough information about the proper vase canopy needed in Poland - where there is not too much sunlight. The important agrotechnical details are: number of boughs and branches, and the shoots pruning system. Pruning ensures good air flow throughout the tree canopy helping to prevent some tree diseases (Demirtas et al., 2010a). According to Demirtas et al. (2010b), summer pruning promotes the accumulation of carbohydrates. According to Sosna and Licznar-Małańczuk (2012) the overly strong growth of apricot trees can be reduced by using adequate rootstock.

The objective of our study was the assessment of the effect of three different canopy forms and the assessment of the shortening of the shoots, on the growth and on the structure of the fruit-bearing zone as well as on the yielding, of three apricot cultivars.

\section{MATERIAL AND METHODS}

A two-factorial experiment was carried out in an experimental orchard in Przybroda near Poznań, Poland during the 2007-2008 time period. Apricot (Armeniaca vulgaris Lam.) trees grafted on apricot seedling rootstock were planted in the spring of 2004, on a grey-brown podzolic soil created on boulder clay. Tree spacing was 4.0 × $2.5 \mathrm{~m}$. The experiment included three apricot cultivars: Goldrich, Hargrand and Sirena. The trees were planted in the spring and pruned to the height of $60 \mathrm{~cm}$. The next year, three forms of tree vase canopy, and shoot shortening performed shortly after blooming time, were applied:

a) vase canopy with 10-12 limbs and branches, shoots shortened by about one half of their length;

b) vase canopy with 7-9 limbs and branches, shoots shortened by about one third of their length;

c) the control consisted of: vase canopy trees with 4-6 limbs and branches, shoots were not shortened at all.

The experiment was established in a random block design with four replications (3 trees in each replication).

Apricot trees bloomed in mid April. The following assessments were carried out: growth, morphology of the fruit bearing zones, and fruit yielding. Fruits were harvested a few times for each cultivar, and always at harvest maturity. Results of the experiment were statistically analyzed using the STAT program, analysis of variance for two-factorial experiments, and the Duncan's test at the significance level of $\mathrm{p}=0.05$.

\section{RESULTS AND DISCUSSION}

In our study, an attempt was made to limit intensive elongation growth of the strongest shoots by shortening them so that a greater number of shoots could be obtained. This treatment was carried out shortly after tree blooming so as not to cause shock and loss of fruit buds. The fruit buds are already present on the 
shortened shoots. In autumn 2007, tree measurement showed that the heading of shoots by one half and by one third of their lengths, contributed to the lowering of 'Goldrich' canopies height, in comparison with the control trees. The canopies of the two other tested cultivars Hargrand and Sirena were not lowered from having their shoots shortened. On the average, the lowest trees included the trees of 'Sirena', while the highest ones were represented by 'Goldrich'. Shoots shortened by one half caused a reduction of tree height in comparison with rest of the trees (Tab. 1). Several authors noticed that tree pruning reduced excessive tree crown height and size (Carlson, 1982; Mika, 1986; Radajewska and Szklarz, 2008; Szklarz and Radajewska, 2009).

In 2007, shoot shortening did not decrease the tree canopy projection. Aside from canopy form and shoot shortening, the tree canopy remained in a similar form. However, the tree canopies differed in the trees of the studied apricot cultivars. The widest canopies were shown by 'Sirena', whose canopy projection was $6.4 \mathrm{~m}^{2}$, while the trees of 'Goldrich' and 'Hargrand' had significantly smaller canopies, showing a projection of 5.0 and $5.4 \mathrm{~m}^{2}$, respectively (Tab. 1).

In 2007, the tree canopy forms and shoot shortening did not cause any significant effect on the increment of trunk cross-section area (TCSA) within the given combination, with the exception of the 'Hargrand' trees. The control trees showed a smaller TCSA in compari- son with trees possessing the highest number of branches. The 'Hargrand' trees had the smallest TCSA, in comparison with the other two studied cultivars (Tab. 1).

The control trees were characterized, on the average, by the smallest number of branched shoots with a diameter $>0.5 \mathrm{~cm}$, on a previous year's shoot, in comparison with trees with shortened shoots in the year 2007. The least number of such shoots was observed, on the average, on the trees of 'Hargrand', while the greatest number was found on the trees of 'Sirena' (Tab. 1). According to Marini $(1984 ;$ 1985), significantly less flower buds were found on branched shoots. Such information is valuable to know when it comes to future fruiting.

In 2007 , on the three studied cultivars, the number of unbranched shoots with a diameter $>0.5 \mathrm{~cm}$ on the shoot from the previous year, was higher in the combination with the greatest number of branches, and with shoots shortened by one half of their length. At the same time, the trees of 'Goldrich' with 7-9 branches and shoots shortened by one third of their length also had more of such shoots, in comparison with the control trees. The control trees were characterized by the smallest number of shoots from the previous year when compared with trees having shortened shoots (Tab. 1). Unbranched, thick shoots, 50$60 \mathrm{~cm}$ long are the most valuable shoots for future fruiting because they develop the most shapely formed fruits. 
M. Szklarz et al.

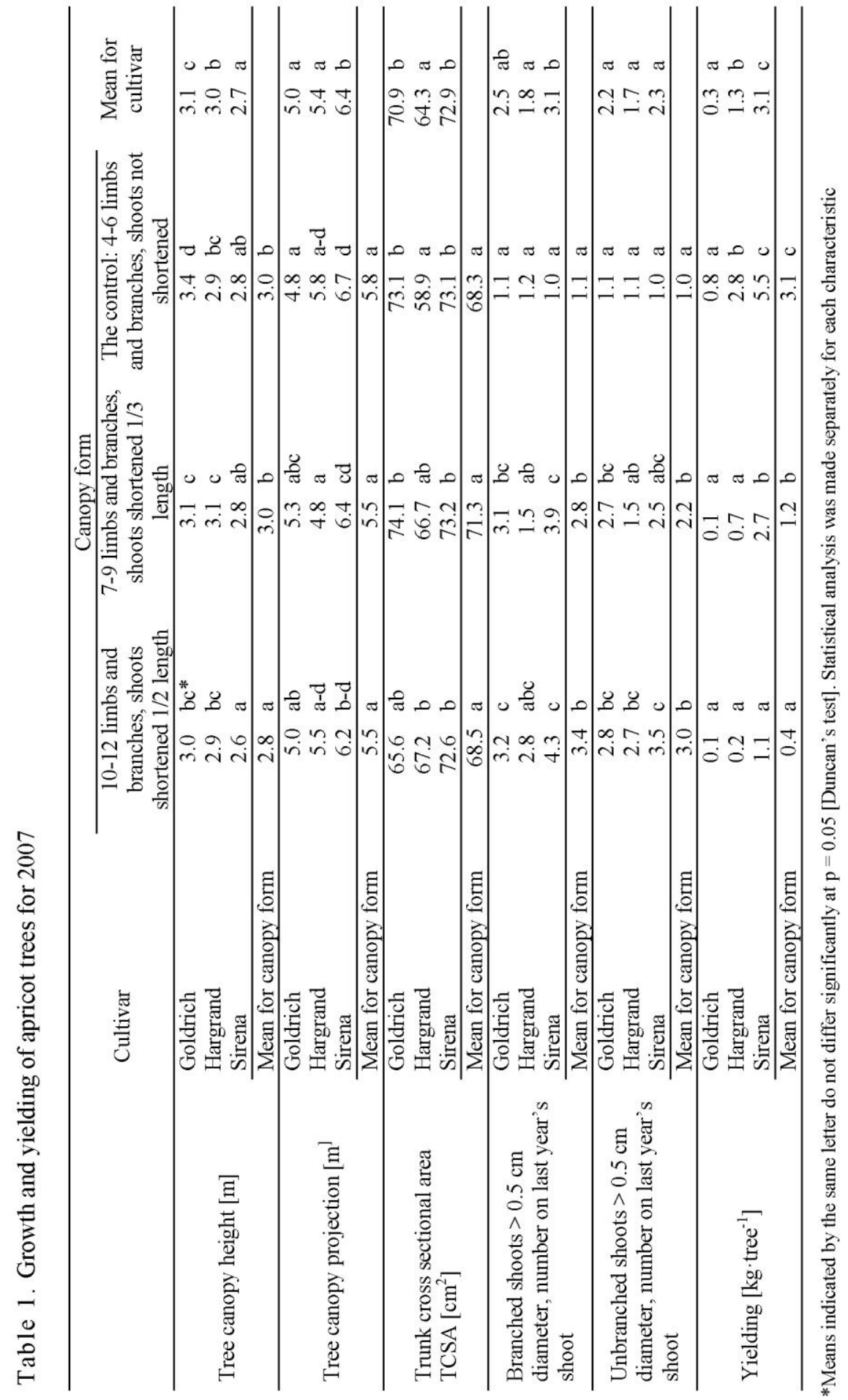


Effects of shoot heading on three canopy...

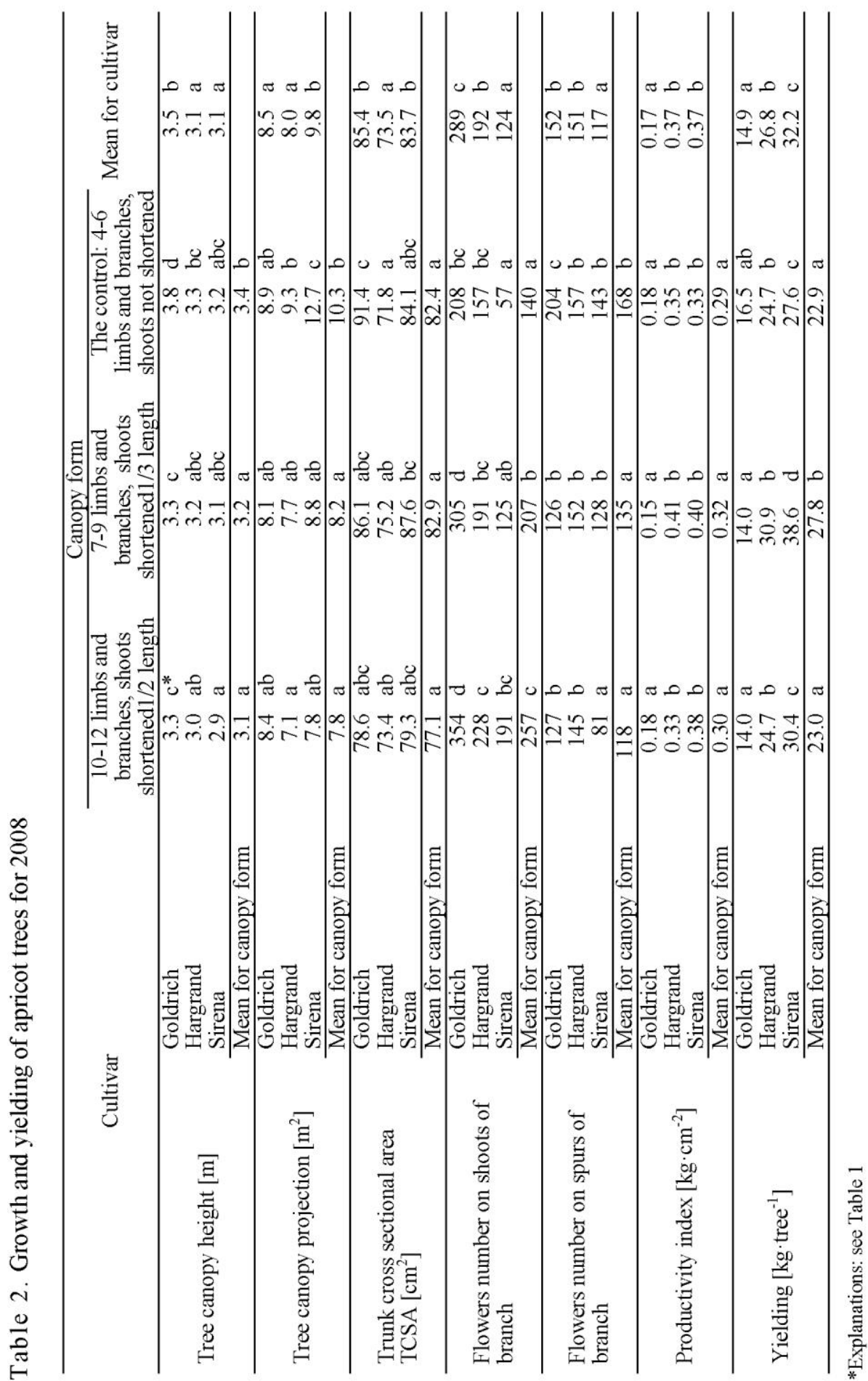


In 2007, early frosts damaged the majority of flower buds. The trees bloomed abundantly, but the fruiting was poor. Within the 'Hargrand', the control trees were fruiting better when compared with the two remaining treatments. According to LicznarMałańczuk and Sosna (2005ab), 'Hargrand' represents one of the cultivars good for commercial production in the Polish region of Lower Silesia because of the cultivar's favourable characteristic features, like: the blooming period, harvest time, fruiting, fruit quality and low susceptibility to Monilinia laxa Sacc. The best yielding was shown by the 'Sirena' control trees, while the poorest yielding was obtained from trees of the same cultivar with the greatest number of limbs and branches, and with shoots shortened by one half of their length. A comparison of the mean results obtained from the analysed cultivars indicated that 'Sirena' yielded in the best way, while 'Goldrich' showed the poorest yielding. In the preceding studies, Szklarz et al. (2011) also found that 'Goldrich' trees gave the poorest yield. On the average, the best was the yielding of the control trees $\left(3.1 \mathrm{~kg} \cdot\right.$ tree $\left.^{-1}\right)$. On the other hand, the poorest yield was shown by the trees with the greatest number of limbs and branches, and with shoots shortened by one half of their length $\left(0.4 \mathrm{~kg} \cdot\right.$ tree $\left.^{-1}\right)$ (Tab. 1).

In 2008, a detailed assessment of tree growth revealed that the form of tree canopy and the shortening of shoots significantly decreased the tree canopy height of the most intensively growing 'Goldrich' whose height surpassed $0.5 \mathrm{~m}$. Generally, 'Goldrich' had the highest canopies compared to the trees of the two other studied cultivars. But, the control trees had the highest canopies, when comparing trees whose shoots had been shortened (Tab. 2).

In 2008, the shoots shortened by one half of their length on 'Hargrand' trees with 10-12 limbs and branches, caused a decreased projection of their canopies. On the other hand, the control trees of 'Sirena' had a significantly greater canopy projection, as compared with the remaining trees of this cultivar. Among trees of the studied cultivars, the 'Sirena' trees had the widest canopy projection, in comparison with the trees of 'Goldrich' and 'Hargrand'. The control trees showed the greatest canopy projection when compared with trees whose shoots had been shortened (Tab. 2).

Within the range of the cultivars studied in 2008, there were no differentiations in the TCSA as far as the vase canopy form and the shortening of shoots was concerned. Only in the 'Hargrand', was the TCSA smaller than in the two remaining cultivars (Tab. 2).

In 2008, trees bloomed abundantly. The number of flowers on shoots, on the branches of the 'Goldrich' control trees, was smaller than the number of flowers on the branches of trees with shortened shoots. On the other hand, on the branches of the control trees of 'Sirena', the number of flowers on shoots was smaller than on the branches of trees with shoots shortened by one half of their length. On the average, the number of flowers on shoots 
of the 'Goldrich' branches was the greatest, while on 'Hargrand', there was an average amount of flowers, and on the shoots of 'Sirena', the number of flowers was the smallest. The canopy type trees with 10-12 limbs and branches, whose shoots had been shortened by one half of their length, had the greatest number of flowers on the shoots of branches, while the control trees showed the smallest number of flowers (Tab. 2). Demirtas et al. (2010a) found that pruning at preharvest time, before bud differentiation, exerted a positive effect on the formation of flower buds on apricot trees. Day et al. (1989); Furukawa et al. (1992) and Myers (1993) found that after pruning different fruit trees, the flower bud formation was better.

In 2008, the number of flowers on spurs of the control cultivar 'Goldrich' was the greatest, in comparison with trees whose shoots were shortened. On the other hand, the trees of 'Sirena' developed the least number of such flowers in the combination with 10-12 limbs and branches, and with shoots shortened by one half of their length, in comparison with the remaining trees of the same cultivar. On the average, the greatest number of flowers on spurs had developed on the branches of 'Goldrich' and 'Hargrand', while 'Sirena' showed the smallest number of flowers. Generally, the canopy form and shoots shortening did not exert any effect on the number of flowers (Tab. 2). According to Marini (1984), there usually appear numerous flower buds on spurs, how- ever fruits developing from them are smaller than the fruits developed on shoots.

In 2008 , the productivity index in the trees of 'Hargrand' and 'Sirena' was high $\left(0.33-0.41 \mathrm{~kg} \cdot \mathrm{cm}^{-2}\right)$, regardless of the canopy form and shoot shortening. On the other hand, in the 'Goldrich' trees, the productivity index was low $\left(0.15-0.18 \mathrm{~kg} \cdot \mathrm{cm}^{-2}\right)$. The differences within the cultivars, though, were insignificant (Tab. 2).

In the discussed year of studies, the number of unbranched shoots with a diameter $>0.5 \mathrm{~cm}$ on the branches of 'Goldrich', was the smallest in the control combination, in comparison with trees whose shoots were shortened. On the trees of 'Goldrich', the mean number of shortened shoots was higher than on the trees of the two remaining cultivars. Trees with 10-12 limbs and branches, and with shoots shortened by one half of their length showed a greater number of such shoots, in comparison with the two remaining types of vase canopy forms (Tab. 3).

In 2008, the canopy type having shortened shoots, had no effect on the average length of unbranched shoots with a diameter $>0.5 \mathrm{~cm}$, on branches within cultivars. At the same time, the mean for cultivar and the mean for canopy type did not show differentiations in this characteristic (Tab. 3).

In 2008, the shoot lengths on the branches of 'Goldrich', were greater in both types of canopies with shortened shoots, in comparison with the control trees. The 'Goldrich' trees showed, on the average, the highest total shoot length on branch, while 
M. Szklarz et al.

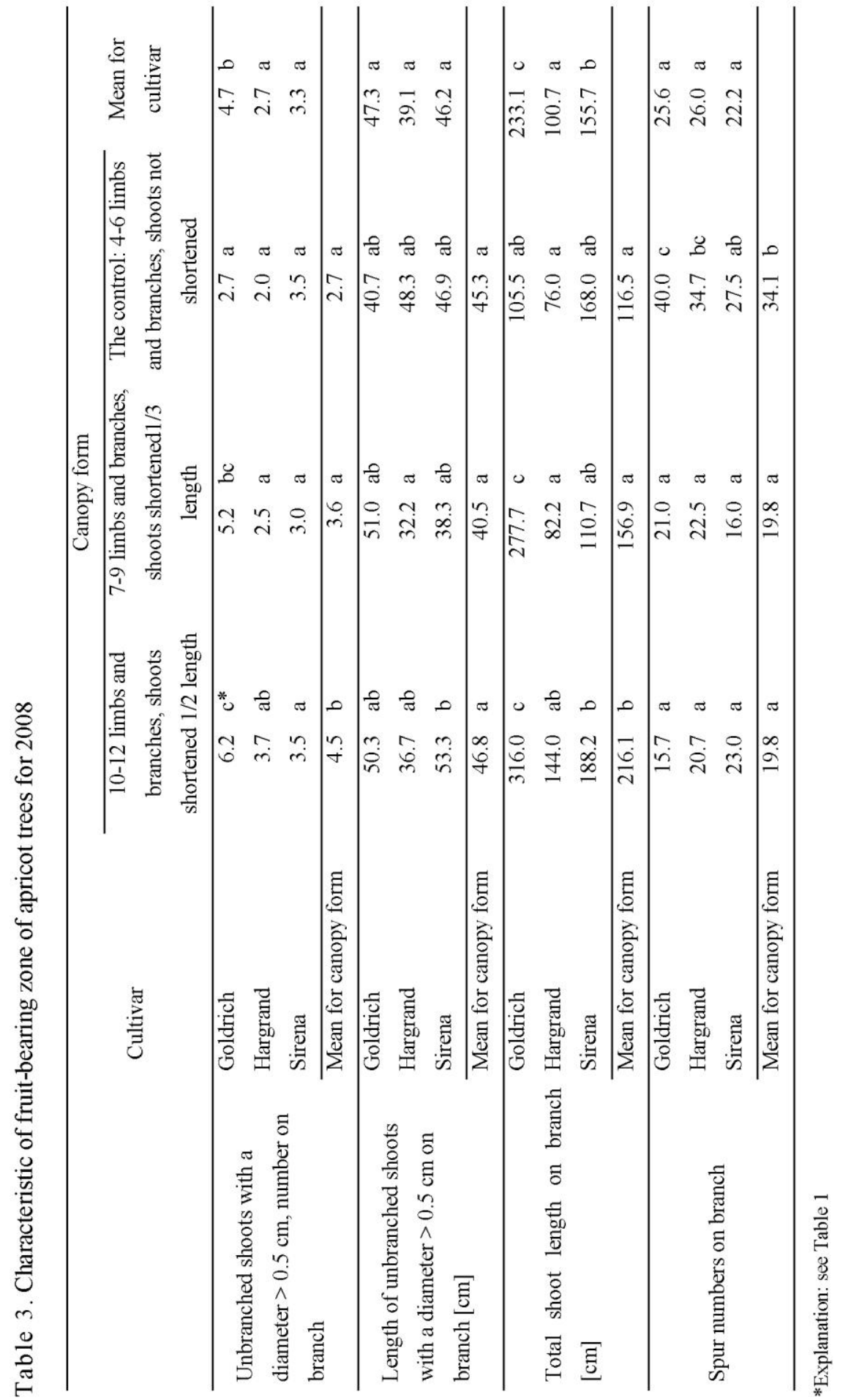


the smallest total shoot length was shown by 'Hargrand'. Generally, the vase canopy form with 10-12 limbs and branches, and with shoots shortened by one half of their length showed the highest summarized length of shoots on branches, in comparison with the two remaining types of canopies (Tab. 3). Radajewska and Szklarz (2009ab) obtained similar results in peach and nectarine trees after an intensive regeneration pruning. The lowest total shoot length was recorded in slightly pruned trees, in comparison with the strongly pruned trees.

In 2008, the control trees of 'Goldrich' and 'Hargrand' had the greatest number of spurs on the branches, in comparison with trees with shortened shoots. Generally, no significant differences were found between the trees of the studied cultivars. On the other hand, in reference to the canopy type and the shortening of shoots, the control trees possessed significantly more spurs than the trees with shortened shoots (Tab. 3). Smaller fruits develop on spurs than on shoots.

In 2008, the yielding of trees was very high. The greatest number of fruits was collected from the trees of 'Sirena' where the trees had a vase canopy with 7-9 limbs and branches, and where shoots had been shortened by one third of their length $\left(38.6 \mathrm{~kg} \cdot\right.$ tree $\left.^{-1}\right)$. Trees of 'Sirena' gave the best yields $\left(32.2 \mathrm{~kg} \cdot \operatorname{tree}^{-1}\right)$, while the trees of 'Goldrich' showed the poorest yielding results $\left(14.9 \mathrm{~kg} \cdot \mathrm{tree}^{-1}\right)$. In 2006 (Szklarz et al., 2011), 'Goldrich' trees also gave the poorest yields.
When we analyze the mean results referring to the canopy type, we can see that trees with a vase canopy having 7-9 limbs and branches, and with shoots which had been shortened by one third of their length, clearly showed a better yielding $\left(27.8 \mathrm{~kg} \cdot\right.$ tree $\left.^{-1}\right)$ than the trees of the two other canopy types $\left(22.9 \mathrm{~kg} \cdot\right.$ tree $^{-1}$ - the control and $23.0 \mathrm{~kg} \cdot \operatorname{tree}^{-1}-$ with 10-12 limbs and branches, and with shoots shortened by one half of their length) (Tab. 2). Son and Kuden (1998) found that 1-year old apricot trees which were pruned in August, gave a much better yield the following year, than the trees which had not been pruned. Demirtas et al. (2010a) reported the highest yield in TSCA was obtained from apricot trees pruned in summer in the preharvest period, while the lowest yield was obtained from trees pruned in summer after harvest. Different tree pruning effects which were specific for different fruit species (peach, plum, sweet cherry) were found by some other authors (Daulta et al., 1986; Miller, 1987; Tehrani and Leuty, 1987; Chitkara et al., 1991).

\section{CONCLUSIONS}

1. Shortening shoots is a favourable treatment for decreasing the height of strongly growing apricot trees.

2. Canopy form and the shortening of the shoots did not influence the increment of trunk cross-sectional area (TCSA) in the studied apricot trees.

3. Shortened shoots improve the structure of the fruit-bearing zone of 
trees. This treatment contributed to the increased number of branched and unbranched shoots with a diameter $>0.5 \mathrm{~cm}$ in comparison with the control trees.

4. The control trees developed more spurs than the trees with shortened shoots.

5. Shortening shoots contributed to an increased number of flowers on shoots but at the same time, it caused a decrease of the number of flowers on spurs.

6. In both years of the study, the trees of the 'Sirena' gave the best yields, while the poorest yields were obtained from the trees of the 'Goldrich'.

\section{REFERENCES}

Carlson R.F. 1982. Fruit tree training and pruning. COMPACT FRUIT TREE 15: 96-98.

Chitkara S.D. Arora R.K., Sharma R.K., 1991. Effect of various levels of pruning on yield and fruit quality in Flordasun peach. HARYANA J. HORT. SCI. 20: 189-192.

Daulta B.S., Devi S., Sing D. 1986. Effect of severity pruning on yield and quality of peach cv. Sharbati. INDIAN J. HORT. 43: 180-183.

Day K.R., Dejong T.M., Hewwit A.A. 1989. Postharvest summer pruning of 'Firebrite' nectarine trees. HORTSCIENCE. 24: 238-240.

Demirtas M.N., Bolat I., Erclisi S., Ikinci A., Olmez H.A., Sahin M., Altindag M., Celik B. 2010a. The effects of different pruning treatments on the growth, fruit quality and yield of 'Hacihaliloglu' apricot systems. ACTA SCI. POL., HORTORUM CULTUS 9(4): 183-192.
Demirtas M.N., Bolat I., Erclisi S., Ikinci A., Olmez H.A., Sahin M., Altindag M., Celik B. 2010b. The effects of different pruning treatments on seasonal variation of carbohydrates in 'Hacihaliloglu' apricot cultivar. NOT. BOT. HORT. AGROBOT. CLUJ. 38(3): 223-227.

Furukawa Y., Kataoka T., Shimomura M., Ogata T. 1992. Productivity of high density peach orchard using a free rootstock (Prunus persica Thunb.). ACTA HORT. 315: 97-102.

Licznar-Małańczuk M., Sosna I. 2005a. Evaluation of several apricot cultivars and clones in the Lower Silesia climatic conditions. Part I: Blossoming of trees, yield and fruit quality. J. FRUIT ORNAM. PLANT RES. 13: 39-48.

Licznar-Małańczuk M., Sosna I. 2005b. Evaluation of several apricot cultivars and clones in the Lower Silesia climatic conditions. Part II: Vigor, health and mortality. J. FRUIT ORNAM. PLANT RES. 13: 49-57.

Marini R.P. 1984. Vegetative growth of peach trees following three pruning treatments. HORT. SCI. 146: 287-292.

Marini R.P. 1985. Vegetative growth, field and fruit quality of peach as influenced by dormant pruning, summer pruning and summer topping. $\mathrm{J}$. AMER. SOC. HORT. SCI. 110: 133139.

McIntyre G.J. 1964. Mechanism of apical dominance in plants. NATURE. 203: 1190-1191.

Mika A. 1986. Physiological responses of fruit trees to pruning. HORT. REVIEW. 8: 339-378.

Miller S.S. 1987. Summer pruning affects fruit quality and light penetration in young peach trees. HORTSCIENCE. 22: 390-393.

Myers S.C. 1993. Preharvest watersprout removal influences canopy light rela- 
tions, fruit quality and flower bud formation of 'Redskin' peach trees. J. AMER. SOC. HORT. SCI. 118: 442-445.

Philips I.D.J. 1975. Apical dominance. ANN. REV. PLANT PHYSIOL. 26: 341-367.

Radajewska B., Szklarz M. 2008. Effect of intensive regeneration pruning of frostbitten peach trees 'Harbinger' $\mathrm{cv}$. on their growth and yielding. ACTA SCI. POL., HORTORUM CULTUS 7(4): 43-56.

Radajewska B., Szklarz M. 2009a. Growth and yielding of peach and nectarine trees after intensive regenerative pruning. FOLIA HORT. 21(2): 77-86.

Radajewska B., Szklarz M. 2009b. Growth and yielding of frostbitten peach trees after regenerative pruning. ACTA SCI. POL., HORTORUM CULTUS 8(4): 11-22.

Son L., Kuden A. 1998. The effect of pruning on yield and fruit quality in Precoce de tyrinthe, Tokaloglu and Karacabey apricots. EKIN J. 4: 48-51.
Sosna I., Licznar-Małańczuk M. 2012. Growth, yielding and tree survivability of several apricot cultivars on Myrobolan and 'Wangenheim prune' seedlings. ACTA SCI. POL., HORTORUM CULTUS 11(1): 2737.

Szklarz M., Radajewska B. 2009. The effect of mulch type and pruning on growth and yielding of nectarine (Prunus persica L.) cv 'Fantasia'. ACTA SCI. POL., HORTORUM CULTUS 8(3): 45-52.

Szklarz M., Radajewska B., Klak T. 2011. Effect of tree pruning and crown formation in young apricot (Armeniaca vulgaris Lam.) trees on their growth and yielding. ACTA SCI. POL., HORTORUM CULTUS 10(3): 63-73.

Tehrani G., Leuty S.J. 1987. Influence of rootstock and pruning on productivity, growth, and fruit size of European plum cultivars. J. AMER. SOC. HORT. SCI. 112: 743-747. 


\title{
WPŁYW SKRACANIA DŁUGOPĘDÓW U TRZECH FORM KORONY WAZOWEJ MORELI (Armeniaca vulgaris Lam.) NA ICH WZROST I PLONOWANIE
}

\author{
Michał Szklarz, Bożena Radajewska, Monika Kluczyńska \\ i Ewa Głowacka
}

\author{
S T R E S Z C Z E N I E
}

Agrotechnika uprawy moreli (Armeniaca vulgaris Lam.) w Polsce jest słabo opracowana. W 2007 roku w Przybrodzie koło Poznania podjęto badania nad formowaniem i cięciem trzech odmian moreli (Goldrich, Hargrand i Sirena) prowadzonych $\mathrm{w}$ trzech formach korony wazowej. Wiosna po kwitnieniu drzew skracano długopędy o 1/2 i 1/3 długości lub nie skracano (w kombinacji kontrolnej). Oceniano wpływ skracania długopędów na wzrost drzew, morfologię strefy owoconośnej, zawiązywanie pąków kwiatowych i plonowanie. Najwyższe korony miały drzewa kontrolne w porównaniu ze skracanymi o $1 / 2$ długości długopędami. Drzewa ze skracanymi długopędami $\mathrm{w}$ porównaniu $\mathrm{z}$ drzewami kontrolnymi miały większą liczbę wartościowych, rozgałęzionych oraz nierozgałęzionych długopędów na ubiegłorocznym przyroście i jednocześnie miały mniej krótkopędów. Najlepszym plonowaniem wyróżniały się drzewa 'Sirena', a najsłabiej plonowały drzewa 'Goldrich'. Drzewa o koronie kotłowej z 7-9 konarami i gałęziami i z długopędami skracanymi o 1/3 długości odznaczyły się lepszym plonowaniem w porównaniu z dwoma pozostałymi formami korony.

Słowa kluczowe: morela (Armeniaca vulgaris Lam.), formowanie, cięcie, morfologia wzrostu, owocowanie 